\title{
Analisis Penerapan Konsep Kaizen Dalam Pengendalian Biaya MutuPada UD. Ridwan 3A Kabupaten Pinrang
}

\author{
Amrizal Salida 1 \\ 1Program Studi Akuntansi, Sekolah Tinggi Ilmu Ekonomi Ichsan Sidenreng Rappang, Indonesia \\ e-mail: amrizal.salida10@gmail.com ${ }^{1}$
}

(Naskah masuk : 6 Mei 2021, Revisi : 18 Mei 2021, Publikasi : 25 Mei 2021)

\begin{abstract}
Abstrak
Analisis Penerapan Konsep Kaizen Dalam Pengendalian Biaya Mutu Pada UD.Ridwan 3A Kabupaten Pinrang. Dalam suatu bidang Usaha Manufaktur perusahaan harus dapat membangun suatu sistem mutu yang senantiasa meningkatkan produknya baik produksi, instalasi maupun kinerja. Penelitian ini bertujuan untuk mengetahui bagaimana penerapan konsep kaizen dapat berpengaruh dalam mengendalikan biaya mutu pada UD.Ridwan 3A Kabupaten Pinrang pada tahun 2018 sampai dengan tahun 2020. Metode pengumpulan data yang digunakan dalam penelitian ini yaitu observasi dan dokumentasi serta kuisioner. Jenis dan sumber data dalam penelitian ini adalah kualitatif dan data yang diperoleh dianalisis dengan metode deskriptif.Hasil penelititan ini menunjukkan bahwa (1) Secara umum, UD. Ridwan 3A telah menerapkan tiga pilar utama yang menjadi aturan dasar dalam menerapkan kaizen. (2) UD. Ridwan 3A masih berusaha melakukan pengendalian biaya mutu yang terjadi dalam kurun waktu antara tahun 2018 hingga tahun 2020.
\end{abstract}

Kata kunci: Biaya Mutu, Kaizen, Kinerja.

\begin{abstract}
Analysis Of The Application Of The Concept Of Kaizen In Charge Of Quality Control At UD.Ridwan 3A Pinrang. In a manufacturing business, the company must be able to build a quality system that continually improves its products, both production, installation and performance. This study aims to determine how the application of the concept of kaizen can be influential in controlling the quality oof the UD.Ridwan 3A Pinrang in year 2018 to 2020. Data collection methods used in this study is the observation and documentation and questionnaires. Types and sources of data in this study was qualitative and the data where analyzed with descriptive methods.The results of this study indicate that (1) generally UD.Ridwan 3A has implemented three pillars of the basic rules in applying kaizen (2) UD.Ridwan 3A is still trying to control the quality cost occurring in the period between 2018 until 2020.
\end{abstract}

Keywords: cost of quality, Kaizen, Performance.

\section{PENDAHULUAN}

Suatu perusahaan yang ingin tetap berkembang dan bertahan hidup di lingkungan bisnis yang semakin kompetitif ini dituntut untuk mampu menghasilkan produk bermutu prima, harga murah, pengiriman tepat waktu, dan pelayanan yang mampu memuaskan pelanggannya semua itu bergantung dengan kualitas produk yang dihasilkan oleh perusahaan.

Kualitas merupakan faktor yang paling dasar untuk kepuasan konsumen. Dalam memproduksi suatu barang tentunya perusahaan harus memperhatikan kualitas dengan tujuan keinginan konsumen dapat terpenuhi oleh perusahaan. Untuk menghasilkan kualitas produk yang baik, kualitas produksi menjadi salah satu perhatian utama yang dilakukan oleh perusahaan dari mulai bahan baku, proses produksi hingga produk akhir. Dalam perkembangan dewasa ini, perusahaan dituntut untuk terus berinovasi meningkatkan efektivitas, efisiensi dan kinerja pada perusahaannya agar dapat bersaing dengan perusahaan lain. (Ira Andespa : 2020)

Dalam proses produksinya, produk cacat merupakan hal yang dapat terjadi. Produk cacat adalah produk yang tidak sesuai dengan spesifikasinya. Produk cacat disebabkan oleh kurangnya pengetahuan dan perhatian mengenai standar mutu. Kurangnya pengetahuan dapat diatasi dengan melaksanakan pelatihan (training) terhadap tenaga kerja. Sedangkan kurangnya perhatian dapat diatasi dengan kepemimpinan yang efektif. Hal tersebut ditunjang dengan proses yang berkelanjutan untuk meningkatkan mutu produknya. Dengan adanya pelaksanaan pelatihan, 
maka tanggung jawab untuk mendeteksi item-item yang tidak sesuai (non-conforming items) dengan standar yang telah ditetapkan akan berpindah dari bagian pemeriksa mutu ke setiap tenaga kerja terlatih yang berhadapan secara langsung dengan masalah yang ditemui.

Setiap perusahaan yang memproduksi suatu barang tentunya harus memperhatikan kualitas mutu produk agar dapat memenuhi standar atau aturan untuk menilai apakah produk yang dihasilkannya itu masuk dalam katagori baik atau produk tidak baik / cacat / Not Good (NG). Produk cacat merupakan produk yang tidak maksimal atau tidak sesuai dengan standar mutu yang ditetapkan oleh perusahaan dalam proses pembuatannya. Produk cacat secara ekonomis dapat diperbaiki dengan menambah biaya tertentu yang menyebabkan perusahaan harus mengeluarkan biaya lebih besar dan rugi akibat tidak tidak terkendalinya produk cacat. (Ira Andespa : 2020)

Untuk mengeliminasi produk cacat dan mencapai cacat nol (zero defect), perusahaan perlu untuk melaksanakan perbaikan secara terus-menerus. Perbaikan secara kontinyu tersebut harus menjadi tanggung jawab semua orang di perusahaan baik itu manajer maupun karyawan. Dengan kata lain, untuk memperoleh mutu yang baik perusahaan perlu untuk menerapkan konsep kaizen.(Kato, Isao dan Smalley : 2012)

Kaizen adalah suatu filosofi dari Jepang, yang mempunyai arti yaitu perbaikan secara terus-menerus berkesinambungan). Kaizen dapat diterapkan dimana saja, baik di perusahaan kecil, menengah, maupun perusahaan besar. Selain itu kaizen juga dapat diterapkan pada bagian produk, proses produksi, mesin maupun manusianya. (Alessia Titusa : 2018)

Dengan menerapkan konsep kaizen diharapkan perusahaan dapat membangun suatu sistem mutu yang senantiasa meningkatkan mutu produknya baik dalam produksi, instalasi, maupun pelayanan serta sekaligus mampu mengendalikan biaya mutu yang terjadi.

Dalam melakukan penelitian ini, peneliti memperoleh rujukan dari penelitian sebelumnya yang dikembangkan, yaitu Sri Ayu Wulandari (2007) dimana ia juga meneliti tentang pengendalian Biaya mutu dengan pendekatan Konsep Kaizen. Peneliti Juga memperoleh rujukan tambahan dari beberapa jurnal yang membahas tentang hal yang sama yaitu Alessa Titussa 2018 dan Ira Andespa 2020.

Tempat penelitian ini di lakukan di UD Ridwan 3A Kabupaten Pinrang. Dimana UD Ridwan 3A Kabupaten Pinrang adalah Usaha yang bergerak di dalam bidang manufaktur atau pembuatan dan produksi berbagai macam perabotan rumah tangga antara lain lemari. UD Ridwan 3A yang tumbuh dan berkembang di era reformasi bertekad untuk menjadikan dan mengembangkan usahanya dengan melakukan perbaikan produksi barang yang dihasilkan secara terus menerus guna memenuhi dan memuaskan kebutuhan dan keinginan konsumennya yang didukung oleh sumber daya manusia yang handal dengan melakukan pelatihan untuk menajamkan skill dan kemampuan serta ramah lingkungan sehingga memberikan manfaat bagi masyarakat sekitarnya.

Berdasarkan uraian di atas, maka fokus penelitian ini adalah bagaimana konsep kaizen dapat berpengaruh dalam mengendalikan biaya mutu yang terjadi pada UD. Ridwan 3A di Kabupaten Pinrang.

\section{METODE}

\section{A. Metode Pengumpulan Data}

Dalam usaha untuk memperoleh data beserta keterangan yang lengkap dalam penelitian ini, maka peneliti menggunakan metode pengumpulan data sebagai berikut:

1. Observasi, yaitu pengumpulan data dengan mengadakan pengamatan langsung terhadap hal-hal yang dianggap perlu dan berkaitan dengan objek penelitian.

2. Dokumentasi, yaitu pengumpulan data dengan mempelajari laporan, formulir, serta catatan yang ada dalam perusahaan.

3. Kuisioner, yaitu responden dari pihak-pihak yang berhubungan dengan permasalahan yang di teliti.

\section{B. Jenis Dan Sumber Data}


Jenis data yang digunakan dalam penelitian ini adalah Data kualitatif, yaitu data yang menjelaskan dan menggambarkan penerapan konsep kaizen dan pelaporan serta pengendalian biaya mutu pada UD Ridwan 3A Kabupaten Pinrang. Sedangkan sumber-sumber data yang dikumpulkan terbagi atas:

1. Data primer merupakan data yang didapat dari pihak-pihak terkait dari pembagian kuisioner.

2. Data sekunder adalah data primer yang telah diolah lebih lanjut dan disajikan baik oleh pengumpul data primer atau oleh pihak lain. Data sekunder dapat berupa catatan, dokumen atau laporan historis (arsip) yang dipublikasikan dan yang tidak dipublikasikan.

\section{Metode Analisa Data}

Metode analisis data yang digunakan dalam penelitian adalah metode deskriptif yaitu menjelaskan penerapan konsep kaizen dalam pengendalian yang berhubungan dengan :

1. Penerapan konsep kaizen di UD Ridwan 3A Kabupaten Pinrang yang meliputi pelaksanaan pada masalah pemeliharaan tempat kerja, penghapusan pemborosan, dan standardisasi.

2. Pengendalian biaya mutu di UD Ridwan $3 A$ Kabupaten Pinrang dengan langkah-langkah dalam analisis data sebagai berikut :

a. Menggambarkan penerapan konsep kaizen di UD Ridwan 3A Kabupaten Pinrang.

b. Mengidentifikasi biaya-biaya yang berhubungan dengan mutu dan menggolongkannya ke dalam biaya pencegahan (prevention cost), biaya penilaian (appraisal cost) serta biaya kerusakan (failure cost) baik internal maupun eksternal.

c. Menganalisis pengendalian biaya mutu dengan metode one year trend, yaitu membandingkan antara biaya mutu yang dikeluarkan perusahaan pada tahun ini dengan tahun sebelumnya.

\section{HASIL DAN PEMBAHASAN}

\section{A. Hasil Penelitian}

Penelitian ini menggunakan análisis deksriktif untuk memberikan penjelasan yang memudahkan dalam menginterprestasikan hasil análisis lebih lanjut. Salah satu caranya dengan mengelompokkan data yang diperoleh dan menyajikannya dalam bentuk tabel.

\section{Gambaran Umum Responden}

Tabel 1 : Pengembalian Kuisioner

\begin{tabular}{lc}
\hline \multicolumn{1}{c}{ Keterangan } & Jumlah \\
\hline Kuisioner yang dikirim sebanyak & 50 \\
Kuisioner yang tidak kembali & $(13)$ \\
Kuisioner yang digunakan & 37 \\
Tingkat pengembalian $(37 / 50 \times 100 \%)$ & $74,00 \%$ \\
\hline
\end{tabular}

Dari tabel 1 dapat dijelaskan bahwa tingkat pengembalian responses rate yang digunakan adalah 74\%. Jumlah tersebut dianggap telah memenuhi syarat dan sudah mewakili dari seluruh karyawan UD. Ridwan 3A dalam penelitian ini.

\section{Identitas Responden}

Dari tabel 2 diketahui bahwa responden jenis kelamin laki-laki lebih banyak yaitu 35 responden sedangkan responden perempuan yang hanya 2 responden dengan total responden sebanyak 37.

Selanjutnya responden dikelompokkan berdasarkan usia dan diketahui bahwa mayoritas responden berusia di atas 25 - 35 tahun yaitu sebanyak 27 responden atau 72,97\%. Kemudian 
mereka berusia antara 36 - 45 tahun sebanyak 8 responden atau 21,62\%. Sedangkan mereka yang berusia 45 tahun keatas sebanyak 2 responden atau $05,41 \%$.

Tabel 2 : Gambaran umum responden

\begin{tabular}{cc}
\hline Keterangan & Jumlah Orang \\
\hline Jenis Kelamin : & 35 \\
Laki-Laki & 2 \\
Perempuan & $\mathbf{3 7}$ \\
\hline Jumlah &
\end{tabular}

Tabel 3 : Jenis Kelamin Responden

\begin{tabular}{ccc}
\hline Keterangan & Jumlah Orang & Persentase \\
\hline Usia : & & \\
$25-35$ Tahun & 27 & $72,97 \%$ \\
36 - 45 Tahun & 8 & $21,62 \%$ \\
45 > Tahun & 2 & $05,41 \%$ \\
\hline Jumlah & $\mathbf{3 7}$ & $\mathbf{1 0 0 \%}$ \\
\hline
\end{tabular}

\section{Pengujian Validitas dan Realibilitas Data}

Tabel 4 : Pengujian Validitas data

\begin{tabular}{cccc}
\hline Variable & Item & Nilai r & Keterangan \\
\hline Konsep Kaizen & P1 & 0,733 & Valid \\
& P2 & 0,646 & Valid \\
& P3 & 0,509 & Valid \\
& P4 & 0,673 & Valid \\
& P5 & 0,616 & Valid \\
& P6 & 0,619 & Valid \\
\hline
\end{tabular}

Dengan melihat hasil pengujian validitas data dapat dilihat nilai $r$ hitung yang dihasilkan lebih besar dari nilai $r$ tabel $(0,320)$, maka dapat dikatakan semua ítem pertanyaan yang digunakan valid. Selanjutnya untuk melihat apakah data yang digunakan dalam penelitian ini handal, maka digunakan uji realibilitas sebagai berikut :

Tabel 5 : Pengujian Realibilitas data

\begin{tabular}{ccc}
\hline Variabel & Koefisien Cronbach & Keterangan \\
\hline Penerapan Konsep Kaizen & 0,738 & Realibel \\
\hline
\end{tabular}

Hasil pengujian realibilitas data yang dilakukan, menunjukkan bahwa variable penerapan konsep kaizen dapat dikatakan realibel karena nilai koefisien Cronbach alpha yang dihasilkan lebih besar dari nilai 0,6 (Sekaran dalam Dwi Priyatno : 2008).

\section{Penerapan Konsep Kaizen}

\section{a. Penerapan Konsep Kaizen untuk pilar Pemeliharaan Tempat Kerja (5R)}

Pemeliharaan tempat kerja atau 5R (Ringkas, Rapi, Resik, Rawat, Rajin) merupakan unsur esensial yang perlu diperhatikan oleh manajemen untuk menerapkan konsep kaizen secara baik. Melalui 5R, karyawan akan mempelajari dan mempraktekkan disiplin diri dalam upaya menghasilkan produk maupun jasa layanan yang bermutu bagi konsumen. Berikut jawaban dari karyawan menyangkut pemeliharaan tempat kerja (5R). 
Tabel 6 : Rangkuman Jawaban Responden

\begin{tabular}{lcccccc}
\hline \multicolumn{1}{c}{ PERTANYAAN } & \multicolumn{7}{c}{ FREKUENSI JAWABAN } & Avera \\
\cline { 2 - 7 } ge
\end{tabular}

Dari tabel diatas dapat diketahui bahwa pada pertanyaan pertama responden yang menjawab pada poin pertama atau STS(sangat tidak setuju) sebanyak 2 responden atau $5,40 \%$, poin kedua TS(tidak setuju) serta ketiga RR(ragu-ragu) tidak ada responden yang menjawab dan pada poin keempat S(setuju) terdapat 24 responden yang menjawabnya atau $64,90 \%$ serta untuk poin kelima SS(sangat setuju) terdapat 11 responden atau 29,70\%. Dan rata-rata jawaban responden berada pada kisaran $4,14 \%$.

Pertanyaan kedua dapat dilihat pada poin pertama dan kedua tidak ada responden yang menjawabnya, poin ketiga terdapat 2 responden atau 5,40\%, poin keempat terdapat 24 responden atau $64,90 \%$ serta poin kelima terdapat 11 responden atau $29,70 \%$ dengan ratarata jawaban responden $4,24 \%$.

Pertanyaan ketiga poin pertama dan kedua serta ketiga tidak ada responden yang menjawabnya, poin keempat terdapat 16 responden atau $43,20 \%$ dan poin kelima terdapat 21 responden atau 56,80\% dengan rata-rata jawaban berada pada kisaran 4,57\%. Hal ini terlihat jelas bahwa penerapan konsep kaizen di perusahaan tampaknya juga mengarah kepada hal tersebut. Hal tersebut dapat dilihat dari diterapkannya sistem kelompok kerja (pokja) yang dibentuk berdasarkan seksi-seksi dan unit kerja - unit kerja yang ada di Perusahaan.

\section{b. Penerapan Konsep Kaizen untuk Pilar Pemborosan}

Penerapan pilar penghapusan pemborosan di perusahaan berkaitan erat dengan penerapan pilar pemeliharaan tempat kerja (5R). Penghapusan pemborosan dan pemeliharaan tempat kerja seringkali berjalan seiring. Fasilitas kerja dimana pemborosan telah dihapuskan, umumnya tertata rapi dan memiliki tingkat $5 \mathrm{R}$ yang tinggi. Berikut jawaban responden tentang penerapan konsep kaizen untuk pilar penghapusan pemborosan. 
Tabel 7 : Rangkuman Jawaban Responden

\begin{tabular}{lcccccc}
\hline \multirow{2}{*}{ PERTANYAAN } & \multicolumn{5}{c}{ FREKUENSI JAWABAN } & Averag \\
\cline { 2 - 7 } & $\mathbf{1}$ & $\mathbf{2}$ & $\mathbf{3}$ & $\mathbf{4}$ & $\mathbf{5}$ & $\mathbf{e}$ \\
\hline $\begin{array}{l}\text { 4. Bagaimana pandangan anda } \\
\text { tentang Perusahaan menghindari }\end{array}$ & 0 & 0 & 0 & 10 & 27 & 4,73 \\
$\begin{array}{l}\text { pemborosan produksi yang } \\
\text { berlebihan. }\end{array}$ & & & & & &
\end{tabular}

\begin{tabular}{lcccccc}
\hline Persentase & $0 \%$ & $0 \%$ & $0 \%$ & $27,00 \%$ & $73,00 \%$ & $100 \%$ \\
\hline $\begin{array}{l}\text { 5. Bagiamana pandangan anda } \\
\text { tentang perusahaan }\end{array}$ & & & & & & \\
$\quad \begin{array}{l}\text { menghindari pemborosan pada } \\
\text { persediaan yang mengakibatkan } \\
\text { biaya menjadi meningkat.. }\end{array}$ & 0 & 0 & 0 & 16 & 21 & 4,57 \\
\end{tabular}

\begin{tabular}{lcccccc}
\hline Persentase & $0 \%$ & $0 \%$ & $11,11 \%$ & $43,20 \%$ & $56,80 \%$ & $100 \%$ \\
\hline $\begin{array}{l}\text { 6. Bagaimana pandangan anda } \\
\text { tentang pengerjaan ulang atas } \\
\text { barang yang gagal produksi atau } \\
\text { cacat. }\end{array}$ & 0 & 0 & 5 & 21 & 11 & 4,16 \\
\hline Persentase & $\mathbf{0 \%}$ & $\mathbf{0 \%}$ & $\mathbf{1 3 , 5 0 \%}$ & $\mathbf{5 6 , 8 0 \%}$ & $\mathbf{2 9 , 7 0 \%}$ & $\mathbf{1 0 0 \%}$ \\
\hline
\end{tabular}

Dari tabel 7 dapat diketahui pada pertanyaan keempat pada poin pertama, kedua dan poin ketiga tidak ada responden yang menjawabnya, poin keempat terdapat 10 responden atau $27,00 \%$ dan poin kelima terdapat 27 responden atau $73,00 \%$ dan rata-rata jawaban responden berada pada kisaran $4,73 \%$.

Sama halnya dengan pertanyaan keempat, pertanyaan kelima pun demikian pada poin pertama, kedua dan ketiga tidak ada responden yang menjawabnya, dan untuk poin keempat terdapat 16 responden atau $43,20 \%$ serta poin kelima terdapat 21 responden atau $56,80 \%$ dengan rata-rata jawaban responden berada pada kisaran $4,57 \%$.

Pertanyaan keenam pada poin pertama dan kedua tidak ada responden yang menjawabnya, poin ketiga terdapat 5 responden atau 13,50\%, poin keempat terdapat 21 responden atau $56,80 \%$ serta poin kelima terdapat 11 responden atau $29,70 \%$ dengan ratarata jawaban responden berada pada kisaran $4,16 \%$.

Hal ini berarti bahwa upaya pendahuluan dalam menerapkan pilar penghapusan pemborosan, Perusahaan mendiskusikan falsafah dan manfaat yang saling terkait antara menerapkan pilar pemeliharaan tempat kerja dan penghapusan pemborosan

\section{c. Penerapan Konsep Kaizen untuk pilar Standarisasi}

Kegiatan bisnis sehari-hari berfungsi mengikuti formula yang telah disepakti bersama. Formula-formula ini, bila ditulis secara ekspilisit, menjadi standar. Standar dirumuskan sebagai cara terbaik dalam melaksanakan suatu tugas. Manajemen yang sukses dalam kegiatan sehari-hari menganut pandangan terhadap tugasnya sebagai : menjaga dan meningkatkan standar. Hal ini tidak hanya berarti sekedar memenuhi tehnologi, manajerial, maupun standar operasional yang berlaku, tetapi juga memperbaiki proses yang ada dalam rangka membawa standar yang ada menuju standar yang lebih tinggi. Standar sebagai sarana untuk mencegah pengulangan kesalahan dan memperkecil variabilitas. Jika kita telah melakukan standardisasi, mamfaat dari kaizen dapat dirasakan dengan hilangnya kesalahan yang tak muncul kembali. Pengendalian mutu adalah pengendalian variabilitas. Tugas manajemen yaitu mengenali, merumuskan, dan menetapkan butir kendali (control point) pada setiap proses dan memastikan bahwa butir kendali tersebut dipatuhi setiap saat. 


\section{Pengendalian Biaya Mutu}

\section{Analisis Biaya Mutu Terhadap Penjualan}

Untuk mengetahui persentase biaya mutu yang terjadi terhadap penjualan, maka dilakukan perhitungan sebagai berikut:

Tabel 8 : Biaya Mutu UD Ridwan 3A

\begin{tabular}{lrrr}
\hline \multirow{2}{*}{ ELEMEN BIAYA } & \multicolumn{3}{c}{ TAHUN PERIODE } \\
\cline { 2 - 4 } PENCEGAHAN & $\mathbf{2 0 1 8}$ & $\mathbf{2 0 2 0}$ \\
\hline Desain Produk & & & \\
Pelatihan & $2,364,894$ & $2,967,626$ & $3,895,458$ \\
& $1,013,526$ & $1,271,840$ & $1,669,482$ \\
\hline Jumlah Biaya Pencegahan & $\mathbf{3 , 3 7 8 , 4 2 0}$ & $\mathbf{4 , 2 3 9 , 4 6 6}$ & $\mathbf{5 , 5 6 4 , 9 4 0}$ \\
\hline PENILAIAN & & & \\
\hline Pengujian & $1,997,460$ & $2,506,545$ & $3,290,220$ \\
\hline Jumlah Biaya Penilaian & $\mathbf{1 , 9 9 7 , 4 6 0}$ & $\mathbf{2 , 5 0 6 , 5 4 5}$ & $\mathbf{3 , 2 9 0 , 2 2 0}$ \\
\hline KEGAGALAN INTERNAL & \multicolumn{3}{c}{} \\
\hline Pengerjaan Ulang & $1,687,626$ & $1,285,662$ & $1,024,541$ \\
Pengujian Ulang & $2,428,534$ & $1,850,098$ & $1,474,334$ \\
\hline KEGAGALAN EKSTERNAL & & & \\
\hline Pertanggungjawaban Produk & $1,193,686$ & 909,370 & 724,675 \\
Penarikan Kembali & $1,225,100$ & 933,302 & 743,746 \\
Perbaikan/Garansi & $\mathbf{7 2 2 , 4 9 4}$ & 550,408 & 438,619 \\
\hline Jumlah Biaya Kegagalan & $\mathbf{7 , 2 5 7 , 4 4 0}$ & $\mathbf{5 , 5 2 8 , 8 4 0}$ & $\mathbf{4 , 4 0 5 , 9 1 5}$ \\
\hline TOTAL BIAYA MUTU & $\mathbf{1 2 , 6 3 3 , 3 2 0}$ & $\mathbf{1 2 , 2 7 4 , 8 5 1}$ & $\mathbf{1 3 , 2 6 1 , 0 7 5}$ \\
\hline
\end{tabular}

a) Perhitungan persentase biaya mutu terhadap penjualan tahun 2018
Biaya Pencegahan
: $3,378,420$
Biaya Penilaian
: $1,997,460$
Biaya Kegagalan
: $7,257,440$
Total Biaya Mutu
: $12,633,320$
$\%$ terhadap Penjualan
: $15,36 \%$
Penjualan Aktual
: 82,200,000

b) Perhitungan persentase biaya mutu terhadap penjualan tahun 2019

Biaya Pencegahan : : 4,239,466

Biaya Penilaian $\quad: 2,506,545$

Biaya Kegagalan $\quad: 5,528,840$

Total Biaya Mutu $\quad: 12,274,851$

\% terhadap Penjualan : : $11,90 \%$

Penjualan Aktual : 103,150,000

c) Perhitungan persentase biaya mutu terhadap penjualan tahun 2020
Biaya Pencegahan
: $5,564,940$
Biaya Penilaian
: $3,290,220$
Biaya Kegagalan
: 4,405,915
Total Biaya Mutu
: $13,261,075$
$\%$ terhadap Penjualan
: $9,79 \%$
Penjualan Aktual
: $135,400,000$ 
Dari perhitungan di atas, dapat diketahui bahwa pada tahun 2018 biaya mutu sebesar $15,36 \%$ dari penjualan aktual sebesar Rp 82,200,000. Biaya mutu aktual tahun 2019 sebesar $11,90 \%$ dari penjualan aktual sebesar Rp 103,150,000 dan biaya mutu aktual tahun 2020 sebesar 9,79\% dari penjualan aktual sebesar Rp 135,400,000. Dari penjelasan tersebut dapat disimpulkan terlihat bahwa persentase biaya mutu pada UD.Ridwan 3A menunjukkan penurunan yang cukup signifikan terhitung mulai pada tahun 2018 sampai dengan tahun 2020. Dan untuk mengetahui perhitungan dan penurunan biaya dalam tiap tahun dapat dihitung sebagai berikut :

\section{Biaya Pencegahan}

Biaya Pencegahan $2018=$ Rp 3.378 .420

Biaya Pencegahan $2019=\mathrm{Rp} 4.239 .466$

Selisih = Rp 861.046

Peningkatan Biaya Pencegahan aktual dari tahun 2018 ke tahun 2019 adalah sebesar Rp 861.046 atau dalam persentase sebagai berikut :

Biaya Pencegahan Tahun 2018 - Biaya Pencegahan Tahun 2019

Biaya Pencegahan Tahun 2019 X $100 \%$

$3.378 .420-4.239 .466$

4.239 .466

Biaya Pencegahan $2019=\mathrm{Rp} 4.239 .466$

Biaya Pencegahan $2020 \quad=$ Rp 5.564.940

Selisih $\quad=$ Rp 1.325.474

Peningkatan Biaya Pencegahan Aktual dari tahun 2019 ke tahun 2020 adalah sebesar Rp 1.325.474 atau dalam persentase sebagai berikut:

Biaya Pencegahan Tahun 2019 - Biaya Pencegahan Tahun 2020

Biaya Pencegahan Tahun 2020

$\mathrm{X} 100 \%$

$4.239 .466-5.564 .940$

\begin{tabular}{llr}
\hline \multicolumn{1}{c}{5.564 .940} & & \\
Biaya Penilaian & & \\
Biaya Penilaian 2018 & $=\mathrm{Rp}$ & 1.997 .460 \\
Biaya Penilaian 2019 & $=\mathrm{Rp}$ & 2.506 .545 \\
Selisih & $=\mathrm{Rp}$ & 509.085
\end{tabular}

Peningkatan Biaya Penilaian aktual dari tahun 2018 ke tahun 2019 adalah sebesar Rp 509.085 atau dalam persentase sebagai berikut :

Biaya Penilaian Tahun 2019 - Biaya Penilaian Tahun 2018

Biaya Penilaian Tahun 2018

$2.506 .545-1.997 .460$

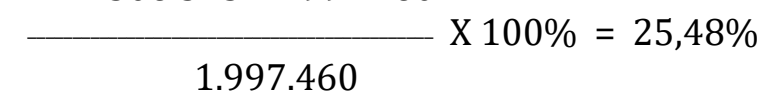

Biaya Penilaian 2019

$=\mathrm{Rp} 2.506 .545$

Biaya Penilaian $2020 \quad=$ Rp 3.290 .220

Selisih

$=\mathrm{Rp} 783.675$ 
Peningkatan Biaya Penilaian aktual dari tahun 2019 ke tahun 2020 adalah sebesar Rp 783.675 atau dengan persentase sebagai berikut :

Biaya Penilaian Tahun 2020 - Biaya Penilaian Tahun 2019

Biaya Pencegahan Tahun 2019

$\mathrm{X} 100 \%$

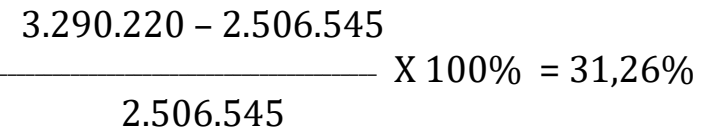

\section{Biaya Kegagalan}

Biaya Kegagalan $2018=\operatorname{Rp~7,257,440}$

Biaya Kegagalan $2019=$ Rp 5.528.840

Selisih $\quad=$ Rp 1.728 .600

Penurunan Biaya Kegagalan aktual dari tahun 2018 ke tahun 2019 adalah sebesar Rp 1.728.600 atau dalam persentase sebagai berikut :

Biaya Kegagalan Tahun 2019 - Biaya Kegagalan Tahun 2018

Biaya Kegagalan Tahun 2018 X $100 \%$

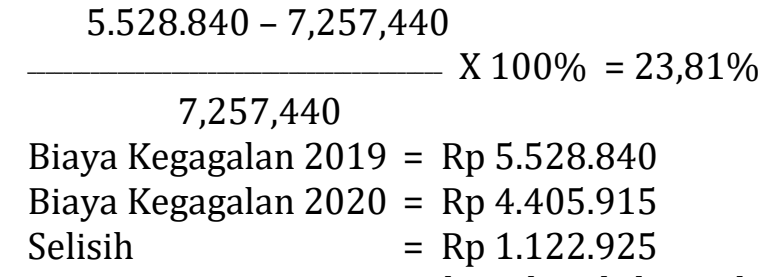

Penurunan Biaya Kegagalan aktual dari tahun 2019 ke tahun 2020 adalah sebesar Rp 1.122.925 atau dalam persentase sebagai berikut :

Biaya Kegagalan Tahun 2020 - Biaya Kegagalan Tahun 2019

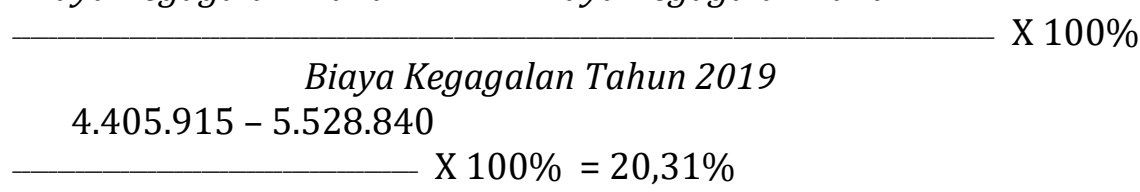

\subsection{8 .840}

Berdasarkan perhitungan di atas, dapat diketahui adanya hubungan yang bersifat berbanding terbalik antara kenaikan biaya pencegahan dan penilaian terhadap penurunan biaya kegagalan dari tahun 2018 sampai dengan tahun 2020. Biaya pencegahan terjadi kenaikan Rp. 861.046 atau sebesar 20,31\% dari tahun 2018 ketahun 2019 sedangkan untuk tahun 2019 ke tahun 2020 meningkat sebesar Rp. 1.325.474 atau sebesar 25,84\% dari tahun 2019 ke 2020. Biaya penilaian mengalami peningkatan sebesar Rp 509.085 atau 25,48\% dari tahun 2018 ketahun 2019 dan untuk tahun 2019 ketahun 2020 mengalami peningkatan sebesar 783.675 atau sebesar $31,26 \%$. Terjadinya peningkatan biaya pencegahan dan penilaian mengakibatkan penurunan untuk biaya kegagalan sebesar Rp 1.728 .600 atau sebesar 23,81\% pada tahun 2018 ketahun 2019, dan untuk tahun 2019 ketahun 2020 mengalami penurunan Rp 1.122.925 atau sebesar 20,31\%.

Selama tahun 2019 sampai dengan 2020 tersebut perusahaan terlihat sudah mampu mencapai efesiensi pengeluaran biaya mutu yang terlihat dari semakin menurunnya presentase total biaya mutu terhadap penjualan aktual pada tahun 2018 sampai dengan tahun 2020 yaitu, sebesar 15,36\% pada tahun 2018, dan 11,90\% pada tahun 2019 dan 9,79\% pada tahun 2020. 


\section{B. Pembahasan}

\section{Penerapan Konsep Kaizen}

Dari hasil penelitian diatas dapat dijelaskan bahwa dengan penerapan konsep kaizen yang di praktekkan secara berkesinambungan dapat memberi efek yang luar biasa dalam perusahaan seperti melatih kedisplinan, bekerja dengan cara-cara yang sederhana namun dengan hasil yang luar biasa dan yang paling utama yaitu mengeliminasi produk cacat yang mencapai cacat nol (zero defect) yang sering terjadi di dalam perusahaan manufaktur, perusahaan perlu untuk melakukan perbaikan secara terus-menerus. Perbaikan secara kontinyu tersebut sudah menjadi tanggung jawab semua orang di perusahaan baik itu manajer maupun karyawan. Sehingga mutu produk dapat meningkat setiap saat dengan menerapkan konsep kaizen. Dasar pemikiran perlunya melaksanakan konsep kaizen adalah bahwa konsep kaizen menekankan suatu perbaikan yang berkesinambungan, tahap demi tahap yang melibatkan semua orang di dalam perusahaan pada hal-hal yang sifatnya kecil, sehingga memerlukan biaya yang rendah.

\section{Biaya Mutu.}

Dari keseluruhan biaya produksi yang diidentifikasi yang menjadi elemen-elemen biaya mutu, dapat diklasifikasikan ke dalam tiga golongan biaya, yaitu:

1. Biaya Pencegahan

a) Biaya Desain Produk, adalah biaya yang dikeluarkan Perusahaan dalam usahanya meningkatkan mutu produknya.

b) Biaya pelatihan mutu adalah biaya ini berkaitan dengan upaya untuk melakukan penelitian mutu kayu dan model lemari sesuai dengan keinginan pasar, pembuatan desain mutu, dan pemberian pelatihan kepada karyawan.

\section{Biaya Penilaian}

Pengujian, adalah biaya yang berhubungan dengan pemeriksaan dan pengujian bahan yang akan digunakan dalam proses produksi

\section{Biaya Kegagalan}

Untuk biaya kegagalan terdapat dua bagian yaitu :

- Biaya kegagalan Internal :

a) Pengerjaan Ulang yaitu biaya yang berkaitan dengan pengerjaan kembali produk yang rusak atau tidak sesuai dengan standar atau spesifikasi yang ditetapkan sehingga pada akhirnya dicapai tingkat mutu yang disyaratkan.

b) Biaya pengujian ulang yaitu biaya yang berhubungan dengan pemeriksaan kembali terhadap produk yang telah ditetapkan yang tidak memenuhi standar mutu.

- Biaya kegagalan Eksternal

a) Pertanggungjawaban Produk yaitu biaya yang berkaitan dengan tanggung jawab perusahaan atas konsumen karena telah menciptakan produk tidak sesuai dengan keinginan konsumen sehingga harus bertanggung jawab memenuhi keinginan konsumen

b) Penarikan kembali yaitu biaya yang berkaitan dengan produk yang konsumen tidak inginkan atas apa yang telah diproduksi oleh perusahaan

c) Perbaikan/garansi adalah biaya yang berkaitan dengan produk yang cacat yang telah diterima oleh konsumen sehingga tugas dari perusahaan adalah memperbaiki produk tersebut.

\section{Pengendalian Biaya Mutu}

Berdasarkan perhitungan hasil penelitian, dapat diketahui bahwa perusahaan sudah cukup mampu mengendalikan biaya mutu secara kontinyu. Hal ini terlihat dengan adanya trend periode biaya mutu individual terhadap penjualan di atas dapat diketahui bahwa perusahaan sudah cukup mampu menurunkan presentase biaya dari tahun 2018 sampai tahun 2020. Ini terbukti dari setiap tahun dari tahun 2018 ke tahun 2020 presentase biaya mutu telah menurun cukup signifikan yaitu pada tahun 2018 sebesar $15.36 \%$ dari penjualan 
aktual, tahun 2019 sebesar $11.90 \%$ dari penjualan aktual dan tahun 2020 sebesar 9,79\% dari penjualan aktual.

\section{KESIMPULAN}

Berdasarkan uraian dan analisis yang telah dipaparkan pada hasil penelitian, maka dapat diambil kesimpulan sebagai berikut, Secara umum, UD. Ridwan 3A telah menerapkan tiga pilar yang menjadi aturan dasar dalam menerapkan kaizen yaitu Penerapan Pilar Pemeliharaan Tempat Kerja (5R), Penerapan Pilar Penghapusan Pemborosan dan Penerapan Pilar Standardisasi, kemudian UD. Ridwan 3A sudah cukup mampu menurunkan presentase pengendalian biaya mutu yang terjadi dalam kurun waktu antara tahun 2018 hingga tahun 2020 .

Berdasarkan uraian dan analisis yang telah dipaparkan pada bab-bab sebelumnya serta kesimpulan di atas, maka dapat diberikan beberapa saran kepada UD. Ridwan 3A sebagai berikut, Perusahaan sebaiknya mempertahankan penerapan konsep kaizen karena terbukti mampu memberikan hasil positif bagi perusahaan. Penerapan konsep kaizen terbukti mampu menciptakan suasana kerja yang kondusif dan pada akhirnya mampu memberikan kontribusi kepada perusahaan dalam peningkatan mutu, penghematan biaya, pengurangan kecelakaan kerja, dan peningkatan produktivitas walaupun secara bertahap. Perusahaan sebaiknya melaksanakan pelaporan biaya mutu secara khusus dan kontinyu supaya dapat diketahui distribusi biaya mutu yang terjadi, sehingga dapat diketahui komponen-komponen biaya mutu yang perlu mendapatkan perhatian. Persentase biaya mutu di UD.Ridwan 3A sudah cukup baik tapi belum terlalu optimal dan ideal. Oleh karena itu, perlu dilakukan strategi untuk menekan biaya mutu supaya mencapai persentase ideal.

\section{DAFTAR PUSTAKA}

Alessia Titusa. (2018). Usulan Perbaikan Produk Crude Palm Oil Dengan Menggunakan Konsep Kaizen Pada PT. XYZ. Semarang

Blocher, Edward J., Kung H. Chen, dan Thomas W. Lin. (2000). Cost Management: a Strategic Emphasis. Edisi Pertama. New York: The McGraw-Hill Companies, Inc.

Feigenbaum, A.V. (2006). Total Quality Control. Dialihbahasakan oleh Hudaya Kundahjaya. Edisi ketiga. Cetakan kedua. Jakarta: Erlangga.

Hansen, Don R. dan Maryanne M. Mowen. (2006). Management Accounting. Edisi Kedua. Cincinnati, Ohio: South-Western Publishing Co.

(2001). Cost Management: Accounting and Control. Edisi Pertama. Jilid 2. Jakarta: Salemba Empat.

Imai, Masaaki. (2008). The Kaizen Power. Diterjemahkan oleh Sigit Prawoto. Cetakan Pertama. Think. Jakarta.

Ira Andespa. (2020). Analisis Pengendalian Biaya Mutu Dengan menggunakan Statistical Quality Control (SQC) Pada PT. Pratama Abadi Industri (JX) Sukabumi. Jawa Barat.

Kato, Isao dan Smalley. Art. (2012). Toyota Kaizen Methods. Diterjemahkan oleh Slamat Parsaoran Sinambela dan Sih Gagas. Cetakan kelima. Yogyakarta: Gradien Mediatama.

Moritani, Masanori. (2006). Japanese Technology: Getting The Best for The Least. Diterjemahkan oleh H.J. Koesoemanto. Yogyakarta: Gadjah Mada University Press.

Mulyadi. (2001). Akuntansi Manajemen: Konsep, Manfaat, dan Rekayasa. Edisi kedua. Cetakan kedua. Yogyakarta: STIE YKPN.

Sulistiono Dhyan. (2003). Analisis Penerapan Konsep Kaizen. Jurnal Manajemen. Universitas Brawijya. Malang.

Ibowo. (2001). Manajemen Kinerja. Edisi Pertama. PT. Rajagrafindo Persada. Jakarta.

William K. Carter, (2005). Cost Accounting. Edisi empat belas. Jilid 1. Jakarta: Salemba Empat. 
